\title{
KARAKTER ATRAKTIF DALAM PERANCANGAN TAMAN PETUALANGAN ANAK
}

\author{
Hastuti Saptorini dan Renata Heryawati Hess \\ Jurusan Arsitektur FTSP Universitas Islam Indonesia, Yogyakarta \\ Jalan Kaliurang Km 14.4 Besi Sleman Yogyakarta 55584 - Indonesia, Phone: 0274-898444 \\ Email: hastuti_saptorini@yahoo.com
}

\begin{abstract}
ABSTRAK
Pembelajaran melalui permainan yang mengandung tantangan dan petualangan membangun karakter kuat dalam hal percaya diri, ketahanan emosi, kerjasama, kecermatan, kecepatan dan kreativitas dalam mengambil keputusan, kepemimpinan, serta sejumlah motivasi lain yang secara prinsip bersifat psikologis. Pendidikan ini bersifat efektif apabila dimulai sedini mungkin, yaitu dari masa anak. Karakternya yang menantang dan menyenangkan, permainan ini menuntut wadah, bangunan, yang dinamis dan atraktif. Bagaimana tolok ukur ungkapan bangunan yang atraktif dan dinamis merupakan arah yang dituju tulisan ini. Melalui penelitian terpadu antara dosen pembimbing dan mahasiswa peserta tugas akhir dengan judul "Pendekatan Psikologis dalam Perancangan Bangunan dengan Studi Kasus Taman Petualangan Anak" atas biaya PHK A-3 Dikti, tolok ukur dapat diperoleh sebagai panduan rancangan. Penelitian ini menggunakan metode deduktif-induktif melalui pendekatan fenomenologis terhadap sejumlah kasus bangunan sejenis. Melalui analisis indukrif telah ditemukan tolok ukur tuntutan arsitektural bangunan yang menjawab atraktivitas dan kedinamisan, serta keamanan pengguna, baik secara kognitf, afektif, maupun psikomotorik. Bentuk masa dan ruang yang organis dengan ketinggian bervariasi, dimensi bangunan berskala anak, komposisi warna polichromatic yang hangat, memaksimalkan komponen landscape dengan vegetasi, air, pola pergerakan yang melingkar, konstruksi yang kokoh, dan tekstur pergerakan yang kasar, merupakan temuan tolok ukur yang dimaksud demi mengakomodasi rasa aman, menyenangkan, mampu membangun imajinasi anak dalam suasana alami.
\end{abstract}

Kata kunci: anak, bermain, atraktif, alami, imajinatif, aman, menyenangkan.

\section{ABSTRACT}

Learning by adventural games has strongly built in self confidence, emotion defensibility, teamwork, creativity and fast in making decision, leadership, are the effective education system if started as soon as possible. That is in child growing period. The challenge and pleasant caracters, these games need the attractive and dynamic performance buildings. By research and design cooperation between supervisor and the final studio student by the title "Psychological Approach in Building Design: Adventure Park for Kids Case Study", funded by the PHK A-3 Dikti, the performance criteria have been found for design reference. The research has used deductive-inductive method by phenomenology approach to the number of the relevant case studies. By inductive analysis method have found the architectural performance criteria of attractive, safety and dynamic building both cognitive, affective, and psychomotoric consideration. The organic and variative elevation of room and building form, kid's scale and room dimension, warm polychromatic colour compotition, maximalize vegetation and water for landscape, rough texture and circle circulation pattern, strong construction, are the findings for accommodating safety, pleasant, imajinative, and natural building image.

Keywords: child, games, attractive, natural, imaginative, safety, pleasant performance.

\section{PENDAHULUAN}

Masa kanak-kanak adalah masa bermain. Konsep ini telah diakui oleh banyak ahli dan sejumlah komunitas, karena secara prinsip, bermain memiliki manfaat terhadap pertumbuhan fisik dan perkembangan mental bagi anak seutuhnya. Sebagai homo ludens, manusia mampu bermain secara hakiki dan memahami arti bermain yang sesungguhnya. Para psikolog pun menggarisbawahi bahwa belajar sambil bermain mampu membangun kreatifitas, karena melalui permainan terbangun suasana yang lepas, bebas, menyenangkan, disertai gerakan yang dinamis dan atraktif.

Dalam merancang bangunan, kebutuhan psikologi merupakan salah satu dari lima human issues: fungsi, sosial, fisik, fisiologis, dan psikologis (Hersberger, 1999:75). Konteks ini membutuhkan pertimbangan yang intensif dalam mengartikulasikan program arsitektur, khususnya dalam mengakomodasi karakteristik dan kebutuhan psikologi pengguna. Karakter ini merupakan tingkat kebutuhan manusia yang paling tinggi untuk mendasari proses artikulasi disain suatu bangunan. Dengan kata lain, ketika suatu 
bangunan didisain atas dasar kebutuhan psikologi penggunanya, maka kebutuhan di atasnya telah melekat menjadi bagian yang dipertimbangkan. Watson dalam Laurens (2004:19) memandang psikologi sebagai ilmu yang mempelajari tentang perilaku karena perilaku dianggap lebih mudah diamati, dicatat, dan diukur. Perilaku itu sendiri memiliki cakupan yang bersifat kasatmata dan tidak kasat mata.

Atraktif merupakan karakter perilaku tidak kasat mata yang tidak hanya bersifat psikomotorik, melainkan juga kognitif dan afektif. Karakter ini memiliki nilai psikologis yang perlu diungkapkan terhadap wadah permainan yang berujud bangunan yang bersifat tantangan. Dalam hal ini Taman Petualangan Anak merupakan bangunan yang beralasan untuk mengakomodasinya.

Taman Petualangan Anak menampung kegiatan perjalanan alam yang memberikan pelajaran tentang pengetahuan hayati, keberanian, ketangkasan, dan percaya diri, melalui pengalaman berpetualang. Semua pertimbangan inilah merupakan alasan mengapa rancangan Taman Petualangan Anak menuntut karakter atraktif. Sehingga, pertanyaan yang perlu dijawab dalam penelitian ini adalah bagaimana tolok ukur perancangan bangunan yang atraktif bagi Taman Petualangan Anak?

\section{LANDASAN TEORI DAN TINJAUAN PUSTAKA}

Architecture is a social art (Hershberger, 1999: 75). Pernyataan ini mengingatkan tugas/kapasitas arsitek dalam memenuhi seni kehidupan manusia ketika merancang suatu bangunan. Keragaman kebutuhan manusia merupakan seni yang dianggapnya sebagai bahan dasar kehidupan sekaligus problematika manusia yang membutuhkan respons arsitektur. Keragaman yang dimaksud terkait dengan 5 problematika kegiatan manusia yang perlu dipertimbangkan dan diartikulasikan dalam program arsitektur. Secara hirarkis, catatan problem kegiatan manusia yang dimaksud tersusun dalam urutan berikut.

1. Disain bangunan mesti mengakomodasi kegiatan yang bersifat fungsional

2. Disain bangunan perlu merawat dan mempertahankan hubungan sosial

3. Disain bangunan harus mempertimbangkan karakter dan kebutuhan pengguna yang bersifat fisik

4. Disain bangunan harus mempertimbangkan karakter dan kebutuhan pengguna yang bersifat fisiologis

5. Disain bangunan harus mempertimbangkan karakter dan kebutuhan pengguna yang bersifat psikologis
Ketika pendekatan psikologi dipandang sebagai perilaku arsitektural, baik yang bersifat kasatmata maupun tidak kasat mata, maka hal ini berkonsekuensi terhadap klasifikasi secara kognitif, afektif, dan psikomotorik. Perilaku yang kasatmata digambarkan sebagai tipologi variasi kegiatan yang dapat ditangkap secara visual, misalnya makan, memasak, bertanam, bekerja, berolah raga, dsb, sedangkan perilaku yang tidak kasat mata dicontohkan sebagai fantasi, motivasi, dan proses yang terjadi ketika manusia bergerak maupun tidak bergerak, yang secara ringkas, klasifikasi perilaku dapat digambarkan sebagaimana dalam Tabel 1.

\section{Tabel 1. Klasifikasi Perilaku}

\begin{tabular}{lll}
\hline Klasifikasi & $\begin{array}{l}\text { Perilaku Kasat } \\
\text { Mata }\end{array}$ & $\begin{array}{l}\text { Perilaku Tidak Kasat } \\
\text { Mata }\end{array}$ \\
\hline Kognitif (rasional) & $\begin{array}{l}\text { belajar, berdiskusi, } \\
\text { dsb }\end{array}$ & $\begin{array}{l}\text { Edukatif, Imajinatif, } \\
\text { Motivasi }\end{array}$ \\
Afektif (emosional) & $\begin{array}{l}\text { Berkumpul, } \\
\text { gembira, senang, }\end{array}$ & $\begin{array}{l}\text { Fantasi, Identitas, } \\
\text { Eksotik, Atraktif }\end{array}$ \\
& $\begin{array}{l}\text { marah, tidak suka, } \\
\text { bangga, dsb }\end{array}$ & \\
Psikomotorik & $\begin{array}{l}\text { Makan, memasak, } \\
\text { (gerakan fisik) }\end{array}$ & $\begin{array}{l}\text { bekerja, bertanam, } \\
\text { berjalan, berolah } \\
\text { raga, dsb. }\end{array}$ \\
\end{tabular}

Sumber: Laurens, 2004: 19 diolah peneliti

\section{Makna dalam Konteks Psikologi dan Arsitektur}

Secara psikologis, kemampuan menangkap makna digambarkan oleh Freedheim et al terbangun melalui 4 periode (2003:144):

1. Sensorimotor period ( 0 th-2 th), yaitu periode pemahaman melalui pengenalan sensori.

2. Preoperational period ( 2 th -7 th), yaitu periode pemahaman melalui simbol dan imej.

3. Concrete-operational period (7th-11th), yaitu periode pemahaman secara konkrit dan mekanistik/ sekuensial/proses dalam melakukan sesuatu.

4. Formal Operation Period (11th-16th), yaitu periode pemahaman intelektual yang tidak hanya bersifat konkret, melainkan lebih bersifat abstrak dan hipotesis.

Adapun secara arsitektural, makna diartikan secara hakiki oleh Laurens atas dasar teori Morris (1938), Gibson (1950), dan Hershberger (1974), sebagai penggunaan sebuah obyek atau suatu lingkungan sehubungan dengan kualitas emosional si pengamat (hal 94). Dalam arsitektur, makna diungkapkan melalui imej, simbol, dan sign. Imej merupakan imitasi atau reproduksi atau kesamaan dari sesuatu. Apabila reproduksi tersebut dikaitkan atau menggantikan sesuatu yang lain (misalnya asosiasi, 
konvensi, institusi,dll) maka makna tersebut termasuk kategori simbol. Simbol merupakan proses kognitif dimana obyek mendapatkan konotasi lain disamping aspek fungsinya. Sedangkan tanda diartikan sebagai bentuk yang secara konvensional disepakati, menggantikan sesuatu dalam arti yang sesungguhnya (nyata) daripada arti yang abstrak.

Hershberger mengkategorikan makna dalam arsitektur dalam 2 macam, yaitu representasional meaning dan referential meaning, yang secara hakiki dijabarkan sebagaimana dalam Tabel 2. berikut.

\section{Tabel 2. Kategori Makna Arsitektural}

\begin{tabular}{|c|c|c|c|}
\hline $\begin{array}{l}\text { Kategori } \\
\text { Makna }\end{array}$ & Jenis Makna & Ciri Umum & Atribut Khusus \\
\hline \multirow{2}{*}{$\begin{array}{l}\text { 1. Makna } \\
\text { Represen } \\
\text { tasional }\end{array}$} & $\begin{array}{l}\text { a. Makna } \\
\text { presentasional }\end{array}$ & $\begin{array}{l}\text { Tidak berbentuk verbal, } \\
\text { melainkan berupa ikon }\end{array}$ & \multirow{2}{*}{\begin{tabular}{|l|} 
Penghayatan \\
melalui bentuk, \\
tekstur, warna, \\
status, ukuran, \\
dan atribut lain
\end{tabular}} \\
\hline & $\begin{array}{l}\text { b. Makna } \\
\text { referensional }\end{array}$ & $\begin{array}{l}\text { Penghayatan terhadap } \\
\text { simbol bagi obyek atau } \\
\text { peristiwa/kegiatan }\end{array}$ & \\
\hline \multirow[t]{3}{*}{$\begin{array}{l}\text { 2. Makna } \\
\text { Responsif }\end{array}$} & $\begin{array}{l}\text { a. Makna } \\
\text { Afektif }\end{array}$ & $\begin{array}{l}\text { Perasaan dan emosi } \\
\text { seseorang ketika melihat } \\
\text { suatu bentuk bangunan. } \\
\text { Respons ini didasari oleh } \\
\text { pengalaman dan budaya } \\
\text { pengguna }\end{array}$ & \multirow[t]{3}{*}{\begin{tabular}{|l} 
Sistem \\
Komunikasi \\
melalui \\
komponen \\
bangunan
\end{tabular}} \\
\hline & $\begin{array}{l}\text { b. Makna } \\
\text { Evaluatif }\end{array}$ & $\begin{array}{l}\text { Penghayatan seseorang } \\
\text { terhadap representasi dan } \\
\text { emosi seketika } \\
\text { berdasarkan } \\
\text { kompetensinya } \\
\end{array}$ & \\
\hline & $\begin{array}{l}\text { c. Makna } \\
\text { Preskriptif }\end{array}$ & $\begin{array}{l}\text { Penghayatan seseorang } \\
\text { untuk melalukkan sesuatu } \\
\text { setelah menglihht dan } \\
\text { mengevaluasinya }\end{array}$ & \\
\hline
\end{tabular}

Sumber: Laurens, 2004: 112 diolah peneliti

\section{Hubungan Peneliti dan Perancang}

Zeisel (1981) menawarkan metode kooperatif antara perancang dengan peneliti dalam 3 bentuk pilihan yaitu programming arsitektur, review perancangan, dan evaluasi proyek yang telah terbangun (hal 32). Metode kerjasama ini, bagi peneliti, bertujuan untuk meningkatkan kontrol dalam mengetest apakah hasil penelitiannya bisa diaplikasikan dalam rancangan. Peneliti yang menginginkan agar informasi mereka digunakan dan berguna, diperlukan kemampuan mengidentifikasi problem perancang melalui studi perilaku pengguna (h.33).

Bagi perancang, kerjasama ini mendorong mereka untuk lebih mampu melihat kebutuhan, keinginan, dan perilaku pengguna secara spesifik, sehingga diharapkan mampu menghasilkan rancangan yang spesifik pula. Proses sinergis antara peneliti dan perancang terjadi dalam mekanisme ini. Sejauhmana perancang mampu mentransformasikan problematika rancangan yang dihasilkan oleh peneliti merupakan proses kemitraan yang perlu diukur (ditest) kinerjanya. Dalam hal ini posisi perancang bukanlah sebagai sub ordinat peneliti, sehingga apapun hasil transformasi rancangan yang dihasilkan oleh perancang merupakan kontrol peneliti dalam menemukan problematika rancangan melalui perilaku pengguna.

Terkait dengan Taman Petualangan Anak, maka aspek perilaku pengguna menjadi komponen utama kajian penelitian yang nantinya dipakai sebagai landasan perancangan bangunan. Kasus ini memiliki penekanan karakter atraktif yang dibahas secara spesifik untuk mendapatkan parameter penelitian tertentu sebagai sarana pengambilan data di lapangan.

\section{Taman Petualangan Anak}

Taman Petualangan Anak merupakan bangunan pendidikan anak melalui permainan tantangan, yang secara prinsip mengenalkan nuansa petualangan demi melatih ketrampilan anak dalam menghadapi variasi rintangan. Dengan kata lain bahwa taman ini diharapkan mampu mengakomodasi fasilitas yang bersifat membangun mental anak melalui sejumlah tantangan sambil berolah raga secara rekreatif.

Fasilitas ini merupakan sarana belajar untuk membangun mental, baik indoor maupun outdoor sambil berolahraga yang diperuntukkan khusus anak berusia 1-12 tahun. Ragam permainan yang disediakan bersifat individual dan komunal (kelompok). Permainan yang bersifat kelompok bersifat lebih dominan daripada individual, karena hakekat kegiatan ini lebih mengajarkan kebersamaan. Secara kategoris, ragam permainan bangunan ini dapat dicermati dalam Tabel 3. berikut.

Tabel 3. Ragam Permainan berdasarkan Kelompok Umur dan Sifat

\begin{tabular}{|c|c|c|c|}
\hline \multirow{2}{*}{$\begin{array}{l}\text { Kelompok } \\
\text { Umur }\end{array}$} & \multicolumn{2}{|c|}{ Ragam Permainan } & \multirow[t]{2}{*}{ Motivasi Permainan } \\
\hline & Individual & Kelompok & \\
\hline $\begin{array}{l}\text { Begin } \\
\text { (1-5 tahun) }\end{array}$ & & \begin{tabular}{|l|} 
Mandi Bola \\
Jungkat-jungkit \\
Peluncuran \\
Lari Estafet \\
Halang Rintang \\
Naik Tangga \\
\end{tabular} & $\begin{array}{l}\text { Membangun: } \\
\text { a. ketangkasan } \\
\text { b. berfikir cerdas } \\
\text { c. arti kebersamaan } \\
\text { d. interaksi sosial }\end{array}$ \\
\hline $\begin{array}{l}\text { Medium } \\
\text { (6-7 tahun) }\end{array}$ & $\begin{array}{l}\text { Bercocok } \\
\text { tanam }\end{array}$ & \begin{tabular}{|l|} 
Dayung Perahu \\
Pengamatan hewan air \\
\end{tabular} & $\begin{array}{l}\text { Membangun: } \\
\text { a. tanggungjawab } \\
\text { b. ketekunan } \\
\text { c. mencintai alam }\end{array}$ \\
\hline $\begin{array}{l}\text { Hard } \\
\text { (8-12 tahun) }\end{array}$ & \begin{tabular}{|l} 
Panjat \\
Tebing/din- \\
ding
\end{tabular} & \begin{tabular}{|l|} 
Arung Jeram \\
Hutan Gunung \\
Susur Goa \\
Flying Fox \\
\end{tabular} & $\begin{array}{l}\text { Membangun: } \\
\text { a. kepemimpinan } \\
\text { b. percaya diri } \\
\text { c. kebersamaan } \\
\text { d. keberanian } \\
\text { e. pengambilan } \\
\quad \text { keputusan } \\
\end{array}$ \\
\hline
\end{tabular}

Ruh edukasi terletak pada kemampuan membangun akal (kognisi) yang perlu dimiliki anak dalam beberapa aspek. Pemusatan perhatian (daya konsentrasi), kemampuan koordinasi, ketelitian, kecepatan reaksi, antisipasi, imajinasi, merupakan aspek dasar 
kemampuan anak secara kognitif (Setyobroto, 2002:35).

Pendekatan yang bersifat afektif, tidak lain adalah membangun iklim (rasa) menyenangkan bagi anak sehingga terwujudlah olahjiwa sebagai penyeimbang hidup dan kehidupan. Konsep ini merupakan upaya membangun kepribadian anak dalam hal agresivitas, penguasaan diri, ketenangan, keindahan, kepercayaam diri, keuletan, keberanian, dan semangat juang. Faktor kepribadian anak, oleh Morgan dalam Setyobroto, menjadi bagian yang tidak boleh diabaikan dalam konteks berinteraksi dengan komunitasnya. Melalui proses interaksi inilah, kemampuan berfikir dan persepsi (kognisi) anak bisa ditangkap dan diketahui sehingga mekanisme teamwork mampu terbangun.

Pendekatan yang bersifat psikomotorik merupakan bagian utama demi membangun "ketrampilan gerak" yang bermanfaat bagi kesegaran tubuh dan raga. Tipologi perilaku anak untuk setiap macam gerak olah raga yang ditampung dalam pusat kegiatan ini membutuhkan pengamatan intensif agar pemfasilitasan gerak menjadi lebih pas, realistis, aman, dan bermanfaat bagi pertahanan dalam menjaga stamina.

Eugene F Gauron, Weinberg, Gould, dan Jackson, para psikolog dalam Setyobroto (2002:94), mengungkapkan tentang lima macam/kategori strategi pembinaan mental. Pertama adalah terkait dengan fokus perhatian, yaitu strategi melatih konsentrasi. Bagi anak, kemampuan berkonsentrasi merupakan karakter psikis anak yang perlu dibangun melalui proses, bukan biologis bawaan, sehingga membutuhkan latihan demi mencapai suatu sasaran.

Kedua adalah strategi membangun perasaan diri berhasil. Kategori ini merupakan latihan untuk membangun kepercayaan diri demi meraih sesuatu. Rasionalitas akan kemampuan diri diharapkan terbangun melalui proses pemikiran yang realistis. Mengukur kemampuan diri secara riil, dalam hal ini, merupakan arah yang dituju dalam latihan.

Ketiga merupakan strategi kategori relaksasi. Latihan ini adalah teknik persiapan mental anak agar tidak memiliki rasa takut sehingga mengakibatkan stress. Jacobson dalam Setyobroto mengenalkan teknik "progressive relaxation" yang merupakan teknik mengajarkan tegang dan relaks secara progresif sehingga otot badan menjadi sensitif dan fleksibel (lebih menyesuaikan dengan keadaan). Benson (1975) juga memaparkan strategi relaksasi melalui "trancendental meditation” untuk menurunkan tekanan darah, denyut jantung, irama pernafasan, konsumsi oksigen, dan ketegangan otot. Dengan cara ini diharapkan anak mampu berpenampilan secara positif.
Keempat adalah strategi kategori "imagery" yaitu dalam bentuk terapi berangan-angan. Sejumlah psikolog peneliti (Jacobson, 1930; Mahoney, 1974; Meinchenbaum,1977) menemukan strategi imagery melalui membangun bayangan dalam pemikiran seseorang demi merangsang gerakan/aktivitas otot. Teknik terapi ini berasumsi bahwa berangan-angan dalam pikiran dan images (citra) memberikan pengaruh dalam tingkah laku individu.

Kelima merupakan persiapan "arousal" yang merupakan strategi kategori terakhir dalam pembinaan mental. Strategi ini digambarkan oleh Weinberg (1984) sebagai persiapan psikis seseorang dalam menghadapi berbagai kemungkinan/konsekuensi dan resiko. Tugas yang diberikan dalam latihan adalah mensyaratkan kekuatan, kecepatan, dan ketahanan dalam tingkat yang tinggi demi penampilan yang optimal.

Secara arsitektural, kesan relaks akan terwujud ketika seting yang digunakan latihan bersifat alami. Sebagaimana Ancok (2006:3) menggarisbawahi bahwa pelatihan mental yang dilakukan di alam terbuka (bersifat alami) akan membangun keterangsangan emosi dan kegembiraan pada diri peserta. Ditambahkannya, belajar dalam suasana hati yang gembira akan sangat membantu efektifitas proses belajar (Ancok, 2006:17).

Kesan/makna alami semacam ini, oleh Lang (1994) juga digarisbawahi sebagai setting yang mendukung dan membangun pembelajaran bagi anak (h.307). Keindahan panorama alam yang berkesan di hati pengamat menumbuhkan peluang partisipatif penggunanya. Halprin (1979) juga menganggap bahwa melalui lingkungan yang alami, mampu membangun vitalitas dan warna kehidupan penggunanya (h.4).

Dengan demikian, Taman Petualangan Anak merupakan tempat pendidikan, pelatihan, dan rekreasi indoor dan outdoor yang memberikan fasilitas bermain yang 'se-olah-olah' berada di alam bebas yang dapat memupuk jiwa petualang, memiliki kemandirian dan kedewasaan, dikemas dalam 'ruang' proporsi anak-anak, yang mengekspresikan tata ruang sebagai alur cerita yang menarik. Dengan demikian, fasilitas ini memiliki sejumlah tuntutan bangunan yang mengandung 4 muatan variabel: a. nilai alami, b. mengandung nilai tantangan, c. menyenangkan, d. mengandung alur cerita (bermakna).

\section{Kesimpulan Parameter Penelitian}

Parameter penelitian disimpulkan dari kajian pustaka dan landasan teori yang telah dipaparkan di atas. Parameter ini akan digunakan untuk menggali data/informasi di lapangan secara fenomenologis. Tabel 4 berikut merupakan parameter yang dimaksud. 
Tabel 4. Parameter Arsitektural atas dasar Aspek Psikologis

\begin{tabular}{|c|c|c|c|c|c|c|c|c|c|c|c|c|}
\hline \multirow{3}{*}{$\begin{array}{l}\text { Tuntutan } \\
\text { Bangunn }\end{array}$} & \multicolumn{12}{|c|}{ Parameter Arsitektural Atas Dasar Aspek Psikologis } \\
\hline & \multicolumn{5}{|c|}{ Kognitif } & \multicolumn{3}{|c|}{ Afektif } & \multicolumn{4}{|c|}{ Psikomotorik } \\
\hline & $\begin{array}{c}\text { Macam } \\
\text { Ruang }\end{array}$ & $\begin{array}{c}\text { Letk/ } \\
\text { orients }\end{array}$ & $\begin{array}{l}\text { Jrk/ } \\
\text { tinggi }\end{array}$ & Bentk & Dimensi & Skala & Warna & Bahan & \begin{tabular}{|l|} 
Pola \\
\end{tabular} & Lebar & Knstrksi & Tekstur \\
\hline \multicolumn{13}{|l|}{ Alami } \\
\hline \multicolumn{13}{|l|}{ Tantangan } \\
\hline \multicolumn{13}{|l|}{ Menyenangkan } \\
\hline Bermakna & & & & & & & & & & & & \\
\hline
\end{tabular}

Sumber: Analisis Penulis, 2006

\section{METODE PENELITIAN}

Penelitian ini menyentuh persoalan hubungan antara manusia, lingkungan, dan perilaku, yang secara metodologis, substansi akan dikaitkan atas dasar paradigma rasionalistik dengan pendekatan fenomenologis. Model pendekatan ini menekankan pada pemahaman yang holistik terhadap suatu fenomena yang pada akhirnya menghasilkan suatu hipotesis (Haryadi, 1999:21). Secara menyeluruh, kerangka metode penelitian ini dirancang melalui sekuens dengan detail penjabaran sebagai berikut.

\section{Kerangka Model Penelitian}

Secara sekuensial, penelitian ini dilakukan melalui jalur deduktif-induktif. Perilaku responden dan tuntutan arsitektural yang bersifat teoritik dikaji secara deduktif (Tahap I). Dari sinilah ditemukan parameter perilaku yang nantinya dipakai sebagai indikator pengukuran gejala (Tahap II). Penggalian fenomena dilakukan terhadap sejumlah kasus sampel yang terjadi di lapangan (Tahap III). Analisis dilakukan secara induktif melalui pengkategorian fenomena yang disusun atas dasar karakteristik perilaku dan tuntutan arsitektural (Tahap IV). Temuan yang berupa tolok ukur perancangan Taman Petualangan Anak dirumuskan sekaligus sebagai hipotesis. Transformasi disain atas dasar tolok ukur hasil temuan dikemas sebagai kesimpulan penelitian yang merupakan bagian akhir dari penelitian ini. Secara diagramatis, kerangka penelitian digambarkan sbb.

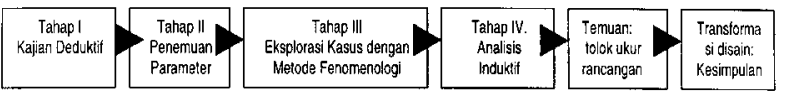

\section{Diagram 1. Kerangka Model Penelitian}

\section{Populasi dan Sampel}

Untuk mendapatkan tolok ukur perancangan dengan karakter atraktif, data dikumpulkan dari sejumlah kasus yang relevan dengan taman bermain anak yang memiliki nilai tantangan. Obyek Wisata Air Bojongsari Purwokerto, Taman Pintar Yogyakarta, sejumlah Fasilitas Pendidikan Pra Sekolah dan
Sekolah Dasar di Yogyakarta, serta sejumlah wisata alam bebas di Sleman, merupakan kasus terpilih sebagai sampel penelitian.

\section{Cara Pengumpulan dan Analisis Data}

Pengumpulan data dilakukan berdasarkan parameter arsitektural yang telah disimpulkan dari Kajian Pustaka dan Landasan Teori. Parameter letak, orientasi, bentuk, konstruksi, warna, bahan, pola, konstruksi, dan tekstur dikumpulkan dengan cara pengamatan, pemotretan, dan pendiagraman, sedangkan parameter jarak, tinggi, dimensi, dan lebar dikumpulkan dengan cara pengukuran. Cara analisis dilakukan dengan metode induktif. Data yang diperoleh diolah dengan cara kategorisasi yang disusun dalam tabel. Kategorisasi didiskripsikan atas dasar karakteristik yang relatif sama dan mendukung parameter teknis arsitektural atas dasar aspek psikologis. Hasil kategorisasi, kemudian ditransformasikan ke dalam rancangan, baik dari sisi tata ruang dan penampilan bangunan.

\section{HASIL SURVEY LAPANGAN DAN PEMBAHASAN}

\section{Tipologi dan Motivasi Pengguna}

Dari sejumlah kasus yang disurvey, terdapat variasi pengguna, dalam hal ini pengunjung, dengan sejumlah ragam motivasi. Secara umum, mereka adalah anak usia pra-sekolah (1-5th), dasar (6-12), menengah (13-18th), mahasiswa, dan orang tua. Dengan kata lain, pengguna fasilitas ini memiliki ranah segala umur, kecuali generasi kakek-nenek. Tingkat social mereka cukup beragam, mulai masyarakat golongan ekonomi bawah, menengah, dan atas Kegiatan ini diimplementasikan seringkali dalam konteks pemanfaatan momentum study tour, liburan sekolah, week-end, olah raga rutin, dan kegiatan sekolah yang bersifat ko kurikuler (misalnya kepramukaan). Tabel 5 merupakan kategorisasi obyek yang disurvey menurut tipologi dan motivasi pengguna (pengunjung). 
Tabel 5. Kategorisasi Pengunjung Menurut Obyek Bangunan yang Disurvey

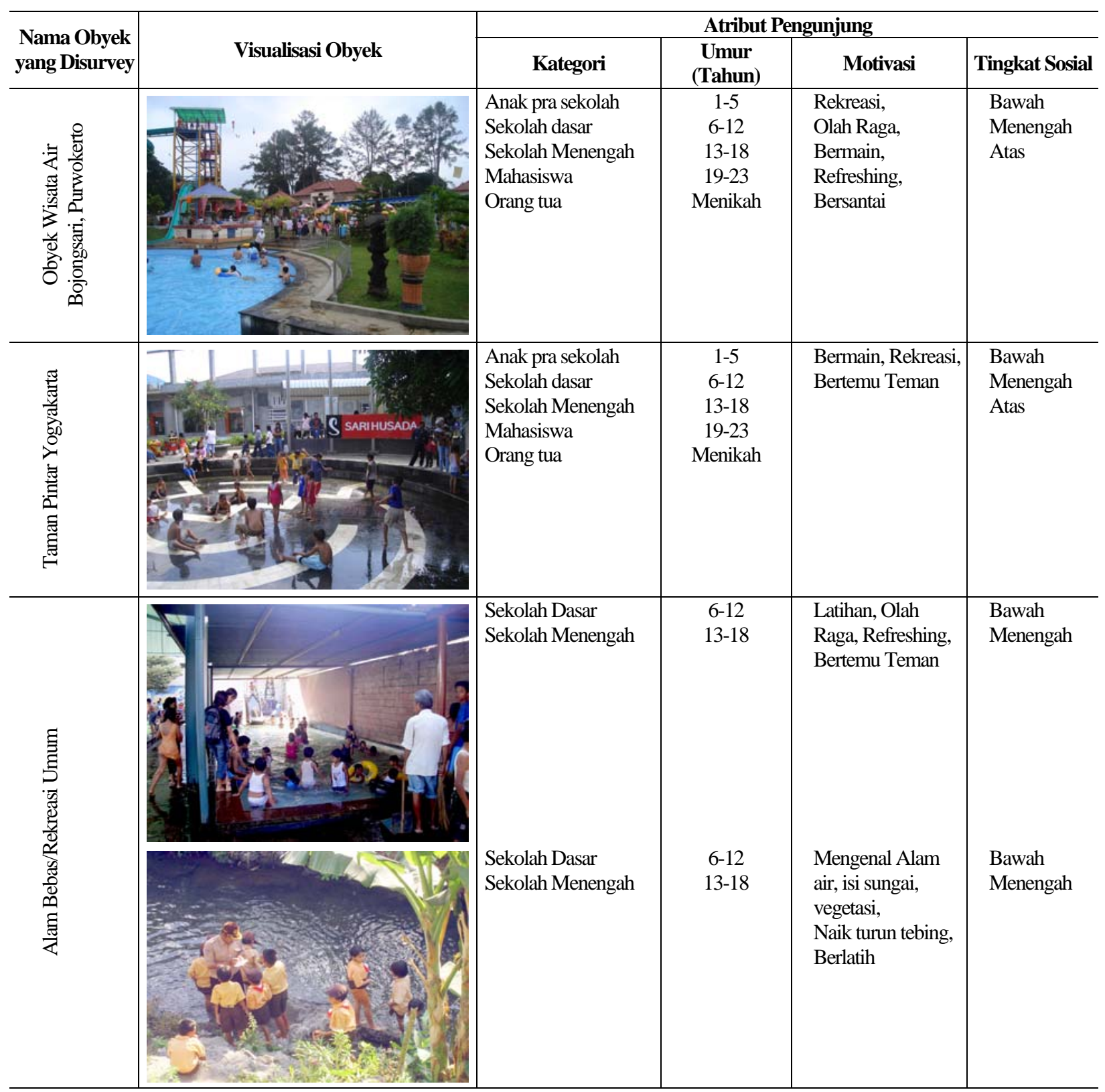

Sumber: Survey Lapangan, Agustus-September, 2006

\section{Tipologi Permainan}

Ditinjau dari tipologi permainan, terdapat macam/ragam permainan yang diminati. Secara umum, mereka cenderung memanfaatkan/merasakan sebanyak mungkin jenis permainan yang tersedia untuk mencoba, membangun pengalaman, dan mengekspresikan kegembiraan. Mencari komunitas yang ramai dan disukai banyak orang juga nampak dalam pengamatan ini. Artinya, mereka cenderung merasa senang apabila permainan yang dipilih diaplikasikan/diikuti oleh banyak orang. Namun begitu, ada kecenderungan dari tipologi pengunjung yang memiliki interest terhadap permainan tertentu. Permainan yang relatif aman, sedikit gerakan dan resiko bahaya, sebagian besar dipilih oleh kelompok anak balita. Mereka lebih memilih permainan yang dekat dengan alam, bersifat eksplorasi, dan meniru gerakan. Sebagaimana teori psikolog Freedheim et al (2003:144) yang menggarisbawahi adanya 4 tahap dalam proses perkembangan anak dalam menangkap makna, bahwa proses pembelajaran dimulai dengan pengenalan/melalui sensori, simbol, sesuatu yang konkrit dan mekanik, dan yang terakhir adalah memahami sesuatu yang abstrak dan memancing hipotesis. Sehingga dalam kategorisasi ragam permainan ditentukan atas dasar tahap perkembangan psikologi ini, yang secara rinci dapat dicermati dalam Tabel 6. 
Tabel 6. Kategorisasi Macam Permainan dan Komponen Dominan Arsitektural Disusun Berdasarkan Kelompok Umur

\begin{tabular}{|c|c|c|c|c|c|}
\hline $\begin{array}{c}\text { Mcm } \\
\text { Permai } \\
\text { nan }\end{array}$ & $\begin{array}{l}\text { Umur } \\
\text { (Tahn) }\end{array}$ & Jenis Permainan & Visualisasi Permainan & Motivasi Permainan & $\begin{array}{l}\text { Komponen } \\
\text { Dominan } \\
\text { Arsitektural }\end{array}$ \\
\hline : & $1-5$ & $\begin{array}{l}\text { Fun Games, } \\
\text { Outbond Kids, } \\
\text { Rumah Tarzan }\end{array}$ & & $\begin{array}{l}\text { Mampu eksplorasi, } \\
\text { Meniru gerakan, } \\
\text { Keberanian }\end{array}$ & $\begin{array}{l}\text { Air yang bergerak, } \\
\text { Aneka Ragam } \\
\text { pepohonan }\end{array}$ \\
\hline 急 & $6-7$ & $\begin{array}{l}\text { Menaiki perahu, } \\
\text { Wisata agro }\end{array}$ & & $\begin{array}{l}\text { Konsentrasi, } \\
\text { Perhatian } \\
\text { Meniru, } \\
\text { Kesimpulan }\end{array}$ & $\begin{array}{l}\text { Air yang bergerak, } \\
\text { sarana pergerakan, } \\
\text { vegetasi }\end{array}$ \\
\hline 㭉 & $8-12$ & $\begin{array}{l}\text { Arung jeram, } \\
\text { Hutan Gunung, } \\
\text { Susur Goa, } \\
\text { Flying Fox, } \\
\text { Panjat Tebing }\end{array}$ & & $\begin{array}{l}\text { Analisis pengetahuan, } \\
\text { Kesimpulan, } \\
\text { Mengambil keputusan }\end{array}$ & $\begin{array}{l}\text { Alami, } \\
\text { Bidang bertebing, } \\
\text { Bebatuan, Air } \\
\text { mengalir deras }\end{array}$ \\
\hline
\end{tabular}

Sumber: Survey Lapangan, Agustus-September, 2006

\section{Komponen Arsitektural}

Secara menyeluruh, ungkapan bangunan yang disurvey dikategorisasikan atas dasar 3 kelompok komponen arsitektural yang tampil secara dominan, yaitu unsur tata ruang luar (lansekap), tata ruang dalam, dan penampilan bangunan. Ungkapan tata ruang luar terkait dengan komponen lansekap, sedangkan tata ruang dalam uraian berhubungan dengan kapasitas permainan, dimensi ruang, dan pola sirkulasi. Adapun penampilan bangunan, ungkapan komponen dikategorisasikan berdasarkan atribut penampilan bangunan.

\section{Tata Ruang Luar (Lansekap)}

Unsur lansekap yang direspons kuat oleh pengunjung adalah terkait dengan unsur alam yang berujud elemen air, vegetasi, perbukitan, dan bebatuan. Khususnya air, elemen ini selalu didekati dan disukai oleh, mulai anak berumur 1 tahun, kelompok remaja, sampai dengan orang tua. Karakternya yang dinamis, air yang bergerak mengungkapkan kesan/ makna yang sensasional, baik secara fisik, rasa, bahkan filosofi sekali pun, sehingga komponen ini selalu "dicari" dan diharapkan kehadirannya dalam arena seperti ini, oleh pengunjung semua umur.

Komponen vegetasi tampil secara dominan dalam kapasitas sebagai background dan pengisi dalam arena permainan. Vegetasi yang dominan membangun karakter/suasana adalah tanaman yang berupa pohon. Keluarga Cemara, palem, jati, dan asam merupakan tipe pohon yang sering muncul dalam bangunan yang disurvey. Tajuknya yang lebar, dan memiliki ketinggian di atas rerata tinggi manusia, secara fisik tanaman ini memiliki sifat mengayomi, dan melindungi pengunjung dari cuaca panas yang terlalu kuat. Di sisi lain, daunnya yang rimbun dengan warna hijau yang pekat memperkuat kesan suasana alami. Demikian halnya kehadiran tanaman perdu dan covering yang berujud rerumputan, memperkuat warna hijau sehingga kesan alami lebih kondusif.

Pola pergerakan air yang berliku, pejalan kaki yang melintas perbukitan dan bebatuan yang mengisi di sela-sela bangunan, menambah kesan tantangan dengan karakter alami yang kuat. Dilapisi dengan nuansa warna coklat kehitaman, komponen ini menggambarkan kesan perjuangan yang menantang.

Simonds (1983) menggarisbawahi bahwa komponen air yang diolah (digerakkan, dialirkan, bahkan dijatuhkan secara mendadak) dalam rancangan tata ruang luar (lansekap) akan mampu menyenangkan dan membahagiakan pengguna (h.50). Semangat ini khususnya dirasakan bagi pengguna yang memiliki instrumen kuat melalui sensori, yaitu komunitas anak.

Kesan menyenangkan dan menggembirakan ini juga diekspresikan melalui jumlah anggota pada setiap macam permainan. Jumlah yang minimal 2 
orang dan rata-rata 6 orang, kecuali permainan panjat tebing merupakan tolok ukur pembelajaran yang menyenangkan dan terkait dengan ungkapan tata ruang dalam karena menyangkut kapasitas setiap macam permainan, yang secara detail dapat dicermati pada tabel 7. Melalui permainan kelompok, maka suasana yang terbangun lebih hangat dan bermakna dalam membangun kebersamaan. Pola sirkulasi pun mendukung suasana ini. Melalui pemilihan pola pergerakan yang organis, maka dinamika permainan lebih mudah terbangun.

Dalam penguraian karakter yang mengandung tantangan dan memiliki makna, sejumlah ungkapan arsitektural telah diekspresikan bangunan yang disurvey. Jalur pergerakan yang berbukit, suasana gelap, air sungai dengan kedalaman antara $75 \mathrm{~cm}-2$ meter, dinding vertikal dengan ketinggian sampai 10 meter, pergerakan kencang, merupakan parameter spesifik yang mengekspresikan tantangan. Sedangkan terbangunnya rasa kebersamaan, keberanian, kedinamisan, senasib seperjuangan, ketangkasan, dan kemampuan berkendali, merupakan makna komponen arsitektural yang berhasil ditemukan. Tabel 7 merupakan kategorisasi komponen pembentuk karakter yang dikelompokkan menurut kesan yang dituntut untuk mengekspresikan karakter atraktif dari sisi eksterior.

Tabel 7. Kategorisasi Ungkapan Tata Ruang Luar Dikelompokkan Berdasarkan Macam Permainan

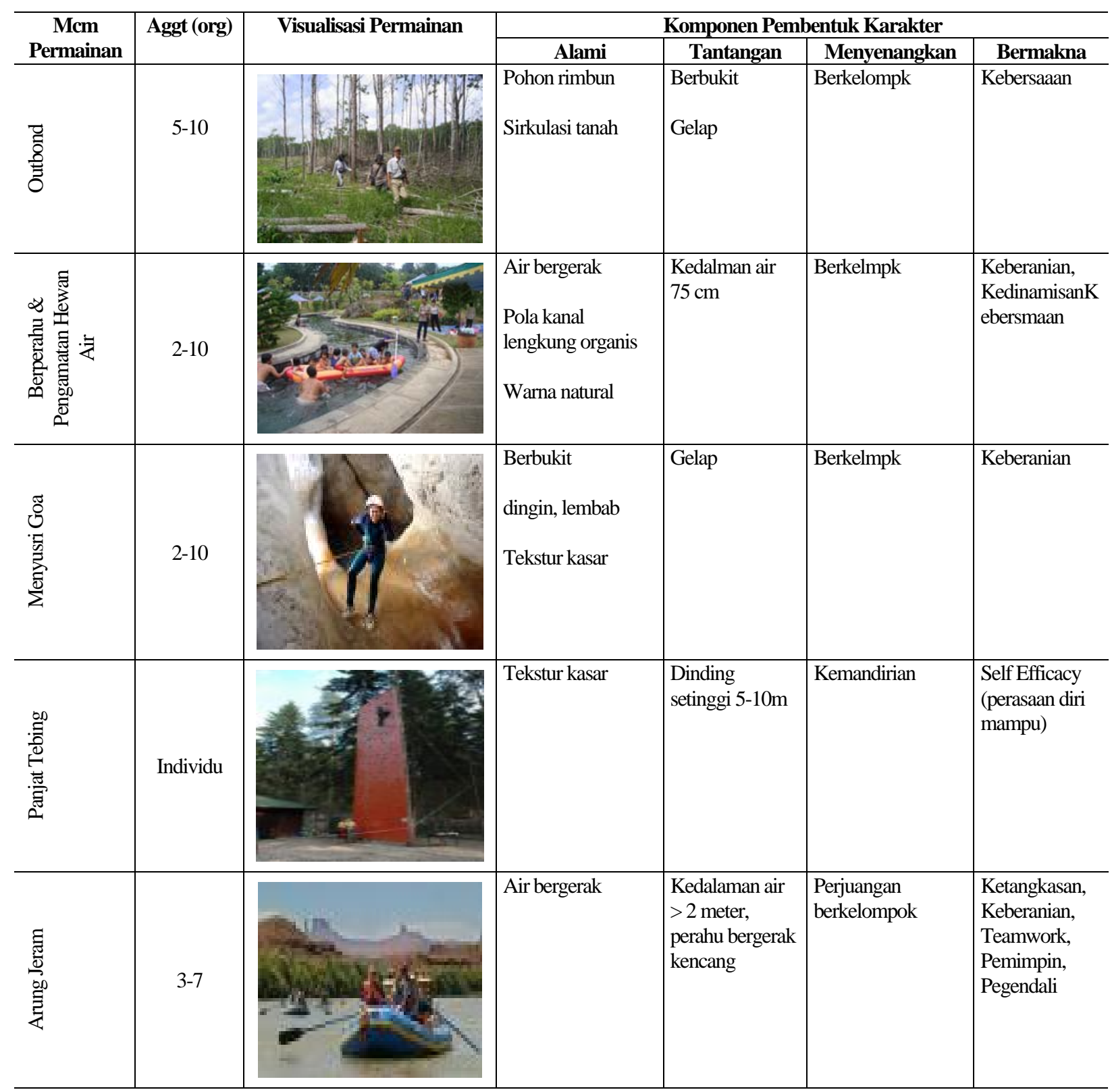

Sumber: Survey Lapangan, Agustus-September, 2006 


\section{Tata Ruang Dalam dan Penampilan Bangunan}

Ekspresi bangunan yang disurvey menunjukkan atribut yang bervariasi dalam mengekspresikan kesan atraktif. Tata ruang dalam secara dominan diungkapkan melalui atribut dimensi, baik tinggi maupun lebar, dan pergerakan/sirkulasi yang diungkapkan melalui konstruksi dan teksturnya. Adapun ungkapan penampilan bangunan ditunjukkan melalui atribut warna, bahan, dan bentuknya. Secara detail kategorisasi ungkapan ini dapat dicermati dalam Tabel 8,9, dan 10 yang masing-masing diklasifikasikan menurut kelompok umur.

Tabel 8. Kategorisasi Ungkapan Tata Ruang Dalam dan Penampilan Bangunan Bagi Kelompok Begin (1-5 tahun)

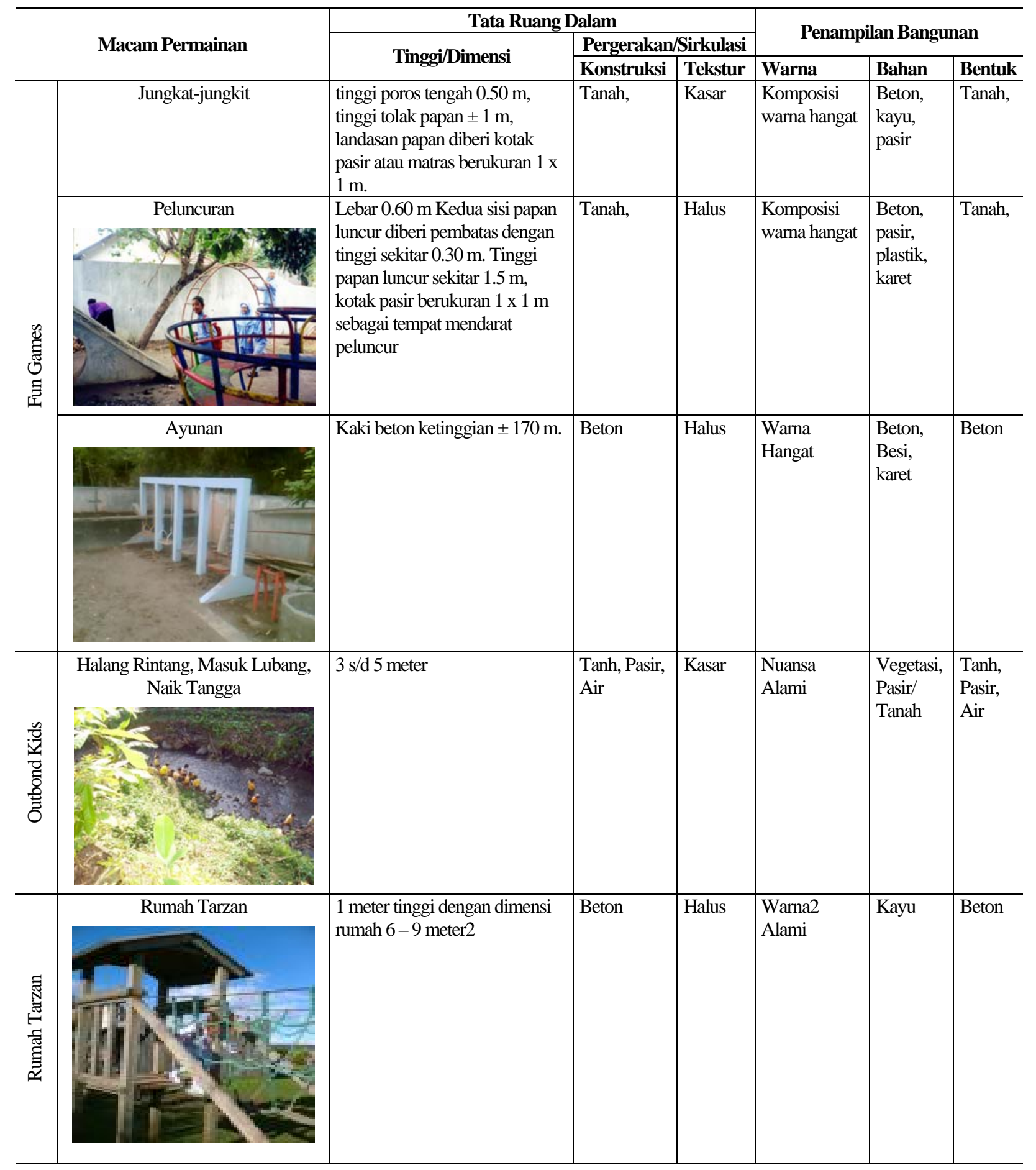

Sumber: Survey Lapangan, Agustus-September, 2006 
DIMENSI TEKNIK ARSITEKTUR Vol. 35, No. 1, Juli 2007: 59 - 72

Tabel 9. Kategorisasi Ungkapan Tata Ruang Dalam dan Penampilan Bangunan Bagi Kelompok Medium (6-7 tahun)

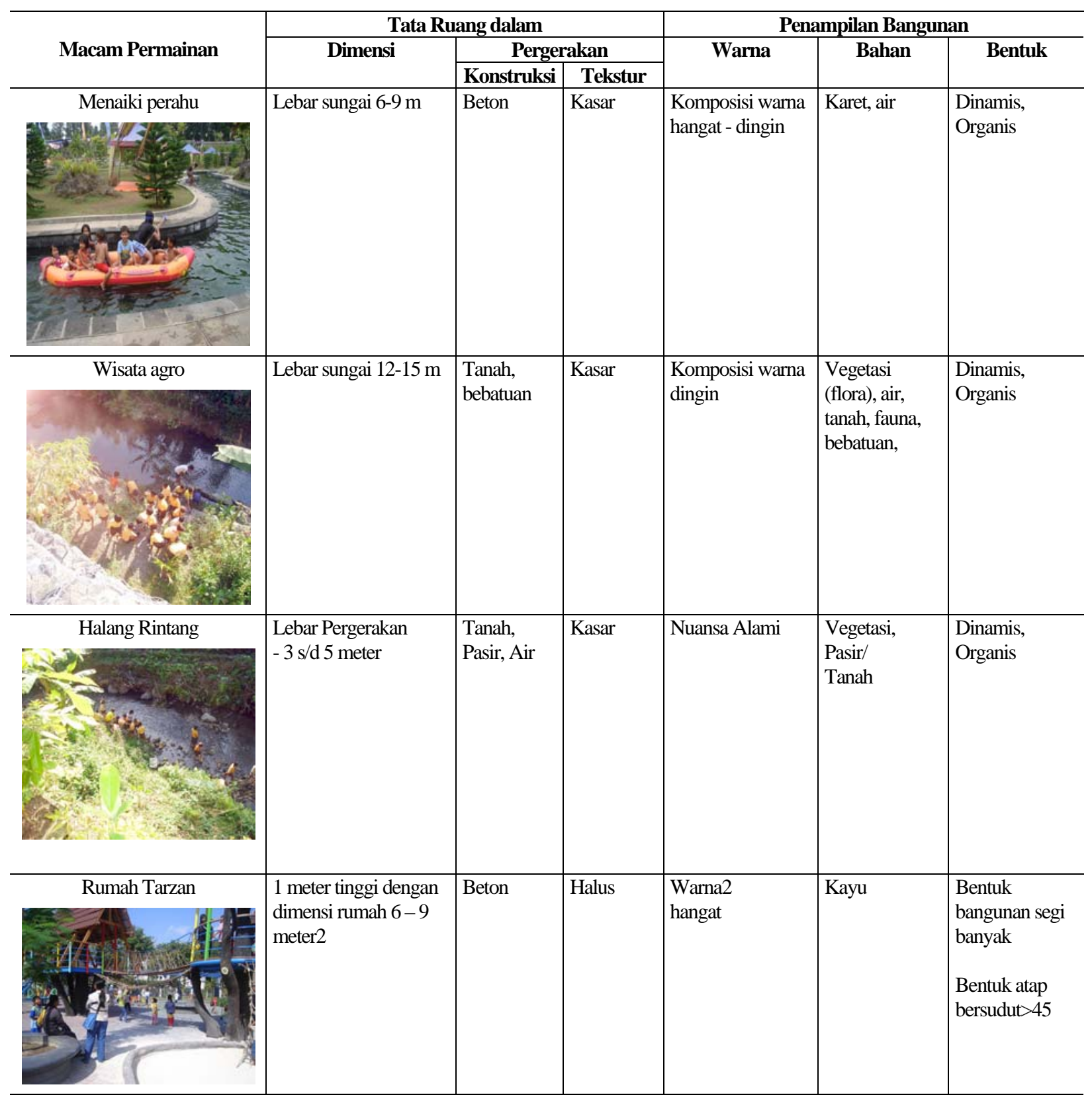

Sumber: Survey Lapangan, Agustus-September, 2006 
Tabel 10. Kategorisasi Ungkapan Tata Ruang Dalam dan Penampilan Bangunan Bagi Macam Permainan Kelompok Hard (8-12 tahun)

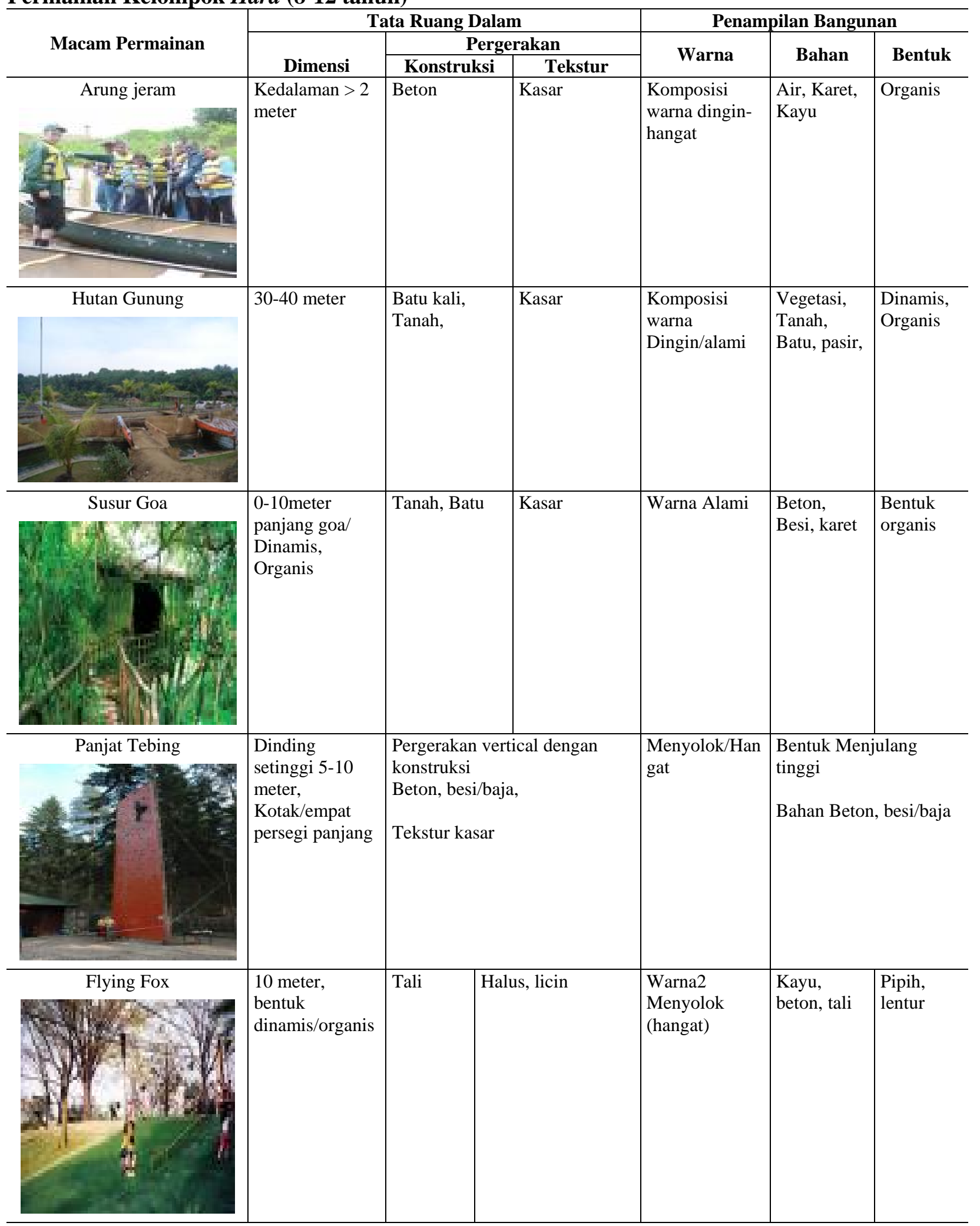

Sumber: Survey Lapangan, Agustus-September, 2006 


\section{KESIMPULAN}

Penerapan tolok ukur rancangan bagi Taman Petualangan Anak yang atraktif didasarkan pada temuan kategorisasi ungkapan arsitektural dari sejumlah kasus bangunan yang disurvey. Sebagai bangunan yang mengakomodasi kegiatan pembelajaran dan latihan mental, bermain sambil berekreasi, Taman Petualangan Anak dirancang atas dasar konsep tata ruang luar yang 'se-olah-olah' berada di alam bebas. Dimensi ruang dalam dikemas sesuai dengan 'ruang' berproporsi anak-anak, yang memiliki estetika lansekap, interior dan penampilan bangunan sebagai pembangkit imajinasi anak.

Transformasi ke tata ruang luar (lansekap) dilandasi oleh pola pergerakan yang dinamis. Dalam hal ini berimplikasi terhadap pola gubahan masa radial dengan jalur sirkulasi menyebar ke sudut-sudut tapak. Transformasi ini merupakan ekspresi pergerakan pengguna dengan sirkulasi yang organis, sebagai harapan tercapainya kesan menyenangkan dari aspek psikomotorik. Open space diletakkan di tengah masa dan di antara lengan sirkulasi dengan memanfaatkannya sebagai kolam yang dikelilingi vegetasi agar berkesan alami. Bentuk masa diungkapkan melalui repetisi bentuk geometris segi empat yang digubah secara bersusun agar dinamis.

Pohon cemara digunakan sebagai tanaman utama dalam rumah pohon, serta berperan sebagai tirai bangunan. Tanaman Soka, Thunbelgia, Melati Costa berada disisi samping bangunan dan batas bangunan, difungsikan sebagai tirai terhadap kegiatan dan pembatas antar macam permainan.

Unsur air diletakkan pada kolam ruang Hall utama, ruang bermain susur Goa, perahu dayung, arung jeram, dsb. Semuanya dialirkan melalui saluran air yang bersumber dari bendungan air sungai yang terletak di sebelah utara site. Posisi bendungan ini dilandasi letak yang menguntungkan karena berada pada posisi kontur yang lebih tinggi dari pada sisi selatan. Fungsi bendungan ini juga berperan penting dalam pengadaan aliran air sungai berkecepatan tinggi, yang digunakan untuk permainan arung jeram.

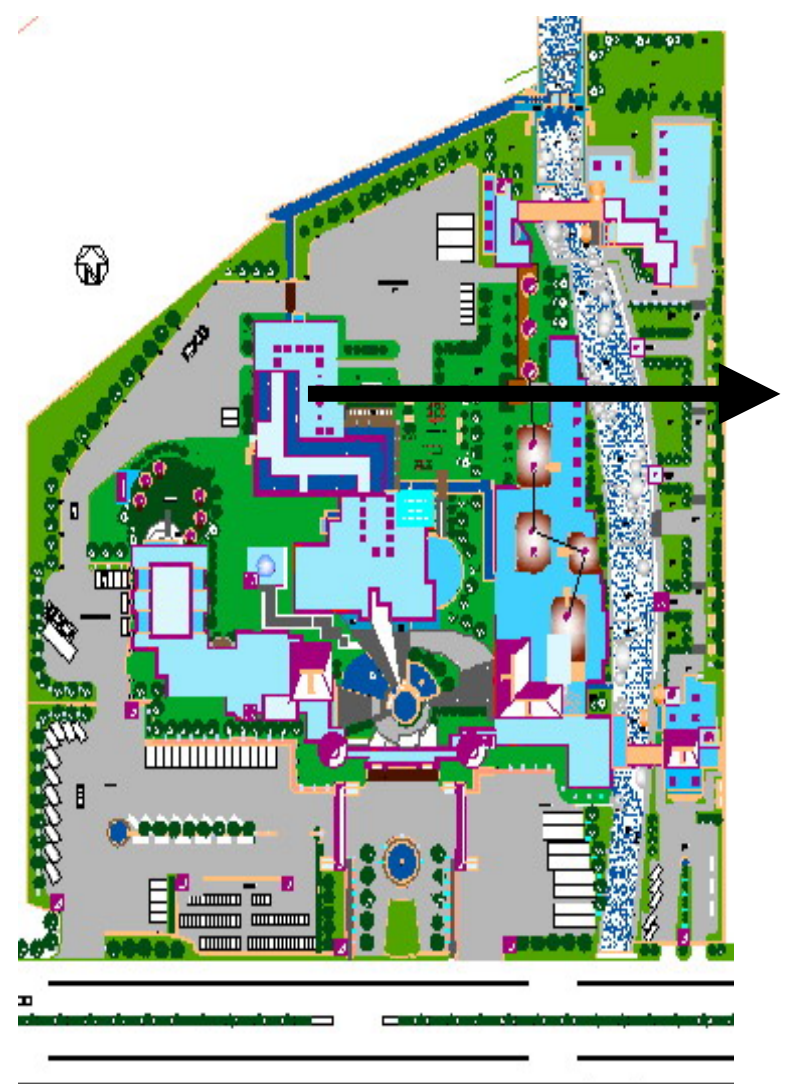

Gambar 1. Ungkapan Siteplan yang mengekspresikan gubahan masa radial, pemanfaatan open space untuk kolam dan pengaturan lansekap yang alami

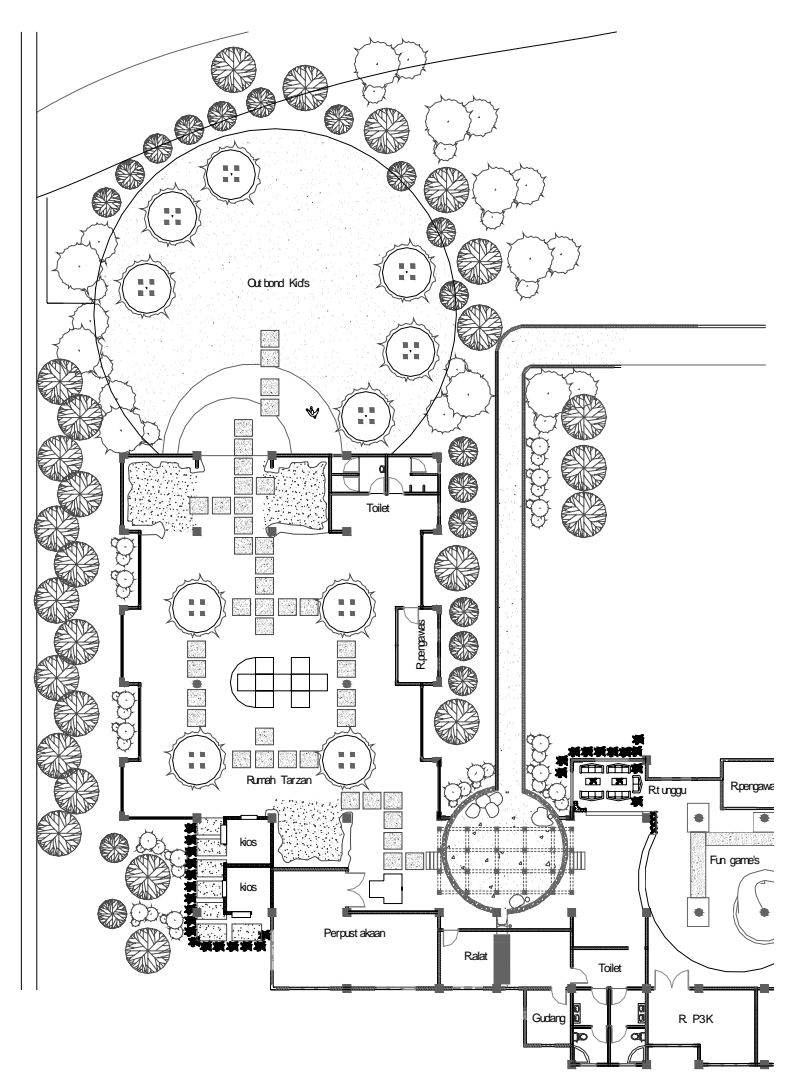

Gambar 2. Denah permainan anak kelompok BEGIN (1-5 th) 


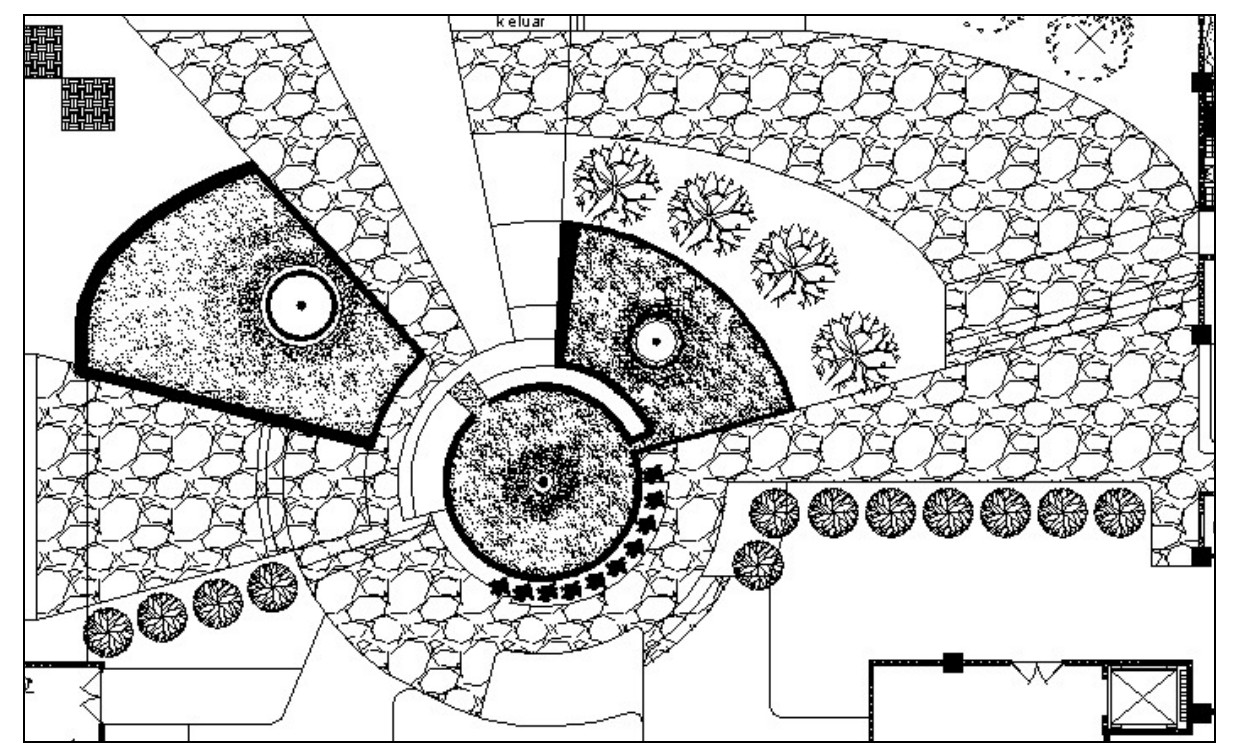

Gambar 3. Komponen Air dan pohon cemara, diletakkan pada Kolam Boulevard, pintu masuk Taman sebagai pintu gerbang yang berkesan alami.
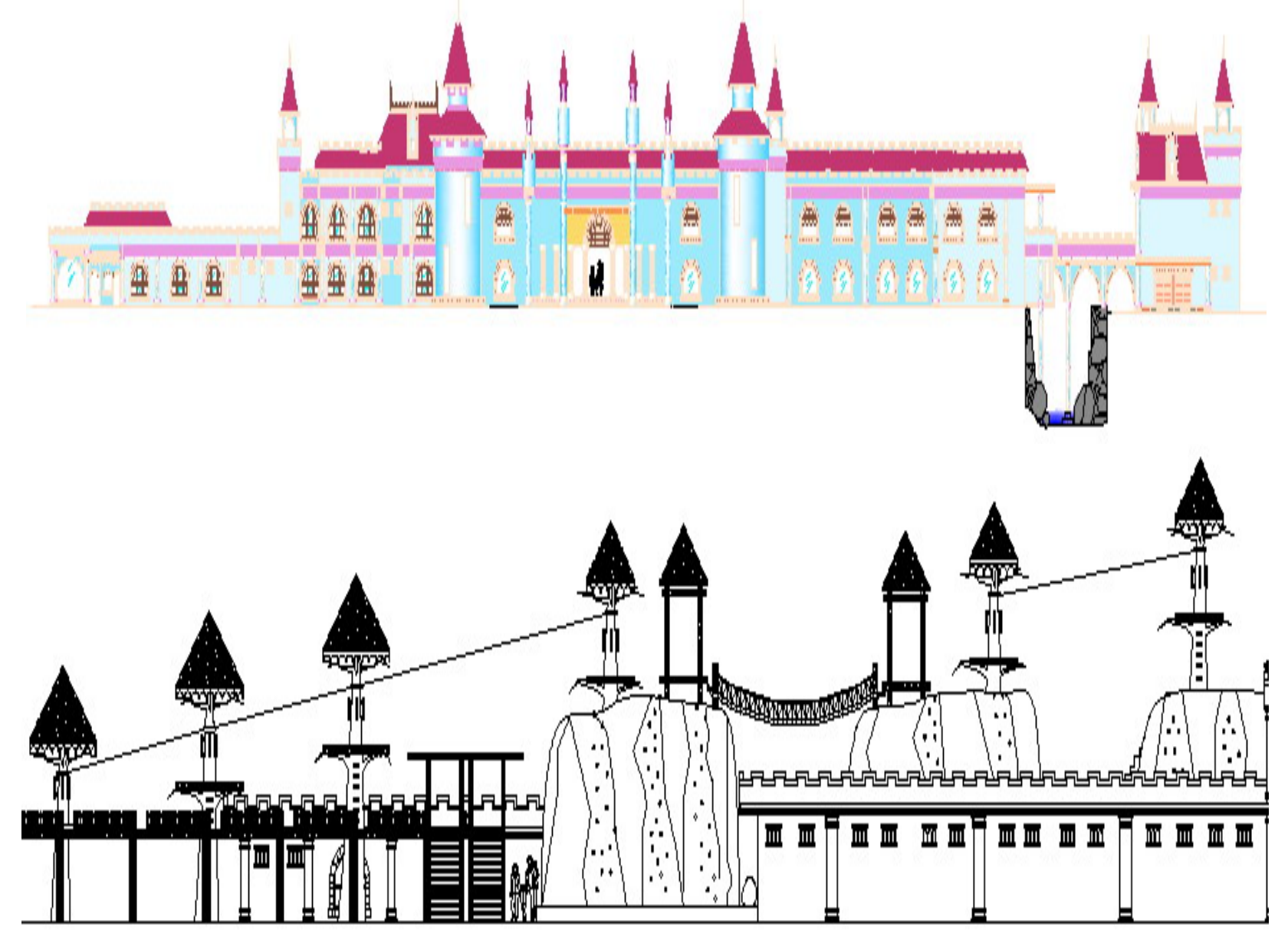

Gambar 4 dan 5. Bentuk atap miring bersudut $>$ 45, dirancang repetisi dan beraksen pada ruang utama, pemilihan warna hangat dan kontras pada mahkota dan dinding ditransformasikan dalam penampilan bangunan demi ungkapan yang imajinatif, menggairahkan, dan menyenangkan anak. 


\section{DAFTAR PUSTAKA}

Ancok, Djamaluddin, 2006, Outbond Manajement Training: Aplikasi Ilmu Perilaku dalam Pengembangan Sumber Daya Manusia, UII, Yogyakarta

Attoe, O. Wayne, 1985, Teori, Kritik, dan Sejarah Arsitektur dalam Pengantar Arsitektur, Erlangga, Jakarta

Freedheim, Donald K., et al, 2003, Handbook of Psychology: vol 1, History of Psychology, John Wiley \& Sons, Inc., New York.

Ginty, Tim Mc., 1985, Rancangan dan Proses Perancangan dalam Pengantar Arsitektur, Erlangga, Jakarta

Halim, Deddy, 2005, Psikologi Arsitektur: Pengantar Kajian LintasDisiplin, Grasindo, Jakarta.

Halprin, Lawrence, 1979, The Collective Perception of Cities in Urban Open Spaces, Rizzoli, Newyork.

Haryadi et al, 1995, Arsitektur Lingkungan dan Perilaku, Proyek Pengembangan Pusat Studi Lingkungan Dirjen Dikti,Depdikbud RI, Jogjakarta.

Hershberger, Robert G., 1999, Architectural Programming and Predesign Manager, Mc. Graw Hill Inc., New York.

Robert G., 1974, Predicting the Meaning of Architecture, Dowden, Hutchinson \& Ross, Inc, Pennsylvania.

Lang, Jon, 1974, Theories of Perception and "Formal" Design in Designing for Human Behavior: Architecture and the Behavioral Sciences, Dowden, Hutchinson \& Ross, Inc, Pennsylvania.

, Jon, 1987, Creating Architectural Theory. The Role of the Behavioral Sciences in Environmental Design, Van Nostrand Reinhold Company, New York.

, Jon, 1994, Urban Design: The American Experience, Van Nostrand Reinhold Company, New York.

Laurens, Joyce Marcella, 2004, Arsitektur dan Perilaku Manusia, Grasindo, Jakarta.

Palmer, Mickey A., 1981, The Architect's Guide to Facility Programming, AIA and Mc. Graw Hill Inc., New York.

Setyobroto, Sudibyo, 2002, Psikologi Olahraga, UNJ, Jakarta
Simonds, John Ormsbee, 1983, Landscape Architecture: A Manual of Site Planning and Design, Mc. Graw Hill Inc., New York

Zeisel, John, 1981, Inquiry by Design, Brooks/Cole Pulishing Company, California 